\title{
粘性土石流の表面流速解析による 流動機構の考察 \\ A DISCUSSION ON MECHANISM OF VISCOUS DEBRIS FLOW VIA SURFACE VELOCITY ANALYSIS
}

\author{
新井宗之 1 劉 雪蘭 2 高橋 保 $^{3}$ \\ 1正会員 工博 名城大学助教授 理工学部土木工学科（テ 468-8502 名古屋市天白区塩釜口一丁目501番地） \\ 2学生会員 工学 名城大学大学院 理工学研究科（†468-8502 名古屋市天白区塩釜口一丁目501番地） \\ 3 フェロー 工博 京都大学教授 防災研究所（テ611-0011 宇治市五ヶ生）
}

The viscous debris flow occurs frequently in the southwest of China. This natural event inflict damage on people or property. For the purpose of mitigation planning, it need to elucidate the mechanism of viscous debris flow. And then, it is necessary to analyze the motion of it.

On July 24th, 1997, a viscous debris flow was recorded with a digital video camera in JiangJia Gully, Dongchuan City, Yunnan Province, China. These images were saved as files formatted as BMP by computer interface board. Since the absolute coordinates of targets which were near the channel were surveyed by an infrared-light distance meter, the distance of a pixel of images about motion of debris flow is estimated in $\mathrm{x}$ and $\mathrm{y}$ direction, respectively. A new image analysis method, the auto-correlation method, is used to analyze the surface velocity of debris flow.

In this paper, the two results of image analysis are shown: one is the mean surface velocity change of central of several surges, another is the change of surface velocity vector in a fixed cross section. According to these results and the field experiment, it could be concluded that viscous debris flow is a kind of complex flow. It is a turbulence in the front of a surge; in the middle of a surge, it could be considered as a kind of cohesive flow; and due to the cohesion or yield strength, the flow almost stops in the end of a surge.

Key Words : Viscous Debris Flow, Observation, Surface Velocity, Mechanism

\section{1. はじめに}

中国では，広い国土で地質，地形，気候の多様性（図 -1）に応じて，様々な土石流の流動タイプが見られる. それらの中の一つは中国の西南部によく分布しているも ので，力学的に定義されたものではないが，粘性土石流 と呼ばれる体積濃度が70\%もある非常に高濃度の流れが ある.この土石流は間欠的に 100 波程度も発生ずる特徴 がある.これらの土石流は，種々の山地災害を引き起こ してきた. このため, 粘性土石流のメカニズムの解明と その対策に関する研究は非常に重要である.

今まで，この粘性土石流の流動メカニズムは大別する と二つの流動モデルが考えられている．一つは粘塑性流 体モデル（ビンガム流体モデル）で，もう一つは粘性流 体モデルである．前者は中国の研究者に多いが，土石流

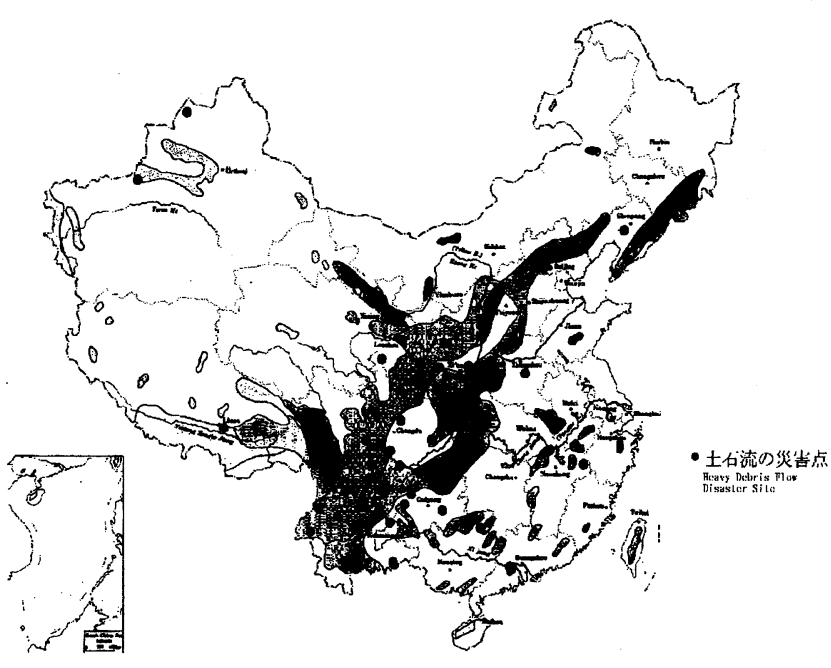

図-1 中国の土石流災害分布 ${ }^{1)}$ 
の流動物質に粘土を 20 ～30\%程度含むことから降伏応力 を有するビンガム流体の一種であると考えるものである. また, 後者は実験や観測から, 粘土を高濃度に含む流れ を一種の粘性流体と考えることができるとするものであ り, 高橋2にによって多くのことが説明されている. しか しながら, 実際の粘性土石流の流動機構を解明するため には，流下現象を解析することが不可欠である.

本研究では近年発達した画像解析手法の中の相関法 (PIV)により, 中国雲南省における蒋家溝で観測された 粘性土石流の幾つかのサージの表面流速の解析を行なつ た. 解析はサージの流心部の平均流速変化, また横断面 の流速変化である. これらの解析結果と現地で行われた 実験結果を比較して, 流動機構について検討した.

\section{2. 粘性土石流の観測条件}

観測流域は中国雲南省東川市における長江の上流の 金沙江という流域の小江の支流である，小江の一支流で ある蒋家溝では流域面積 $48.6 \mathrm{~km}^{2}$, 河道全長は $13.9 \mathrm{~km}$ である (図一2). 粘性土石流を毎年平均約 15 回に発生 することで知られている，最も多い年は28回発生してい る. その流動の特徴は, 土石流がサージとして何度も繰 り返し間欠的に流下寸ること, またこの一連の現象は数 時間にも及び，最大流量は約 $2820 \mathrm{~m}^{3} / \mathrm{s}$, 最大流速は約 $15 \mathrm{~m} / \mathrm{s}$ 程度を有する流れであることである.

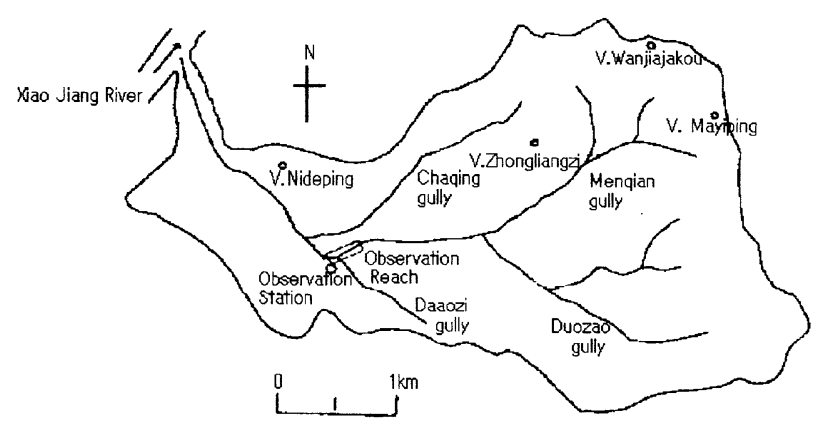

図-2 蒋家溝の流域

蒋家溝で1997年7月 24日午後, 上流域での降雨から 1 時間後, 16:30ごろから21:30ごろまで約5時間, 間欠的 にサージとして流下した. 粘性土石流を観測した中流部 ではほとんど降雨はなかった。

観測された土石流の流下河道は長さ約 $300 \mathrm{~m}$ ，幅約 30 $\mathrm{m}$, 深さ約 $3 \mathrm{~m}$, 水路勾配が約 $5^{\circ}$ のほぼ直線状である

（写真一 1 ） . 河道の両岸に基準点としてターダットT 1〜 T6を設け, 光波測距儀よって相対的な3次元の位置 を定めている(表一1)，流下中の土石流を採泥方法によ り得た。その土砂の粒度分析の一例は図一 3 のようであ り、中央粒径 $d_{50}=5.7 \mathrm{~mm}$ ある。

土石流記録用のカメラは 1 フレーム $1 / 30$ s のデジタ

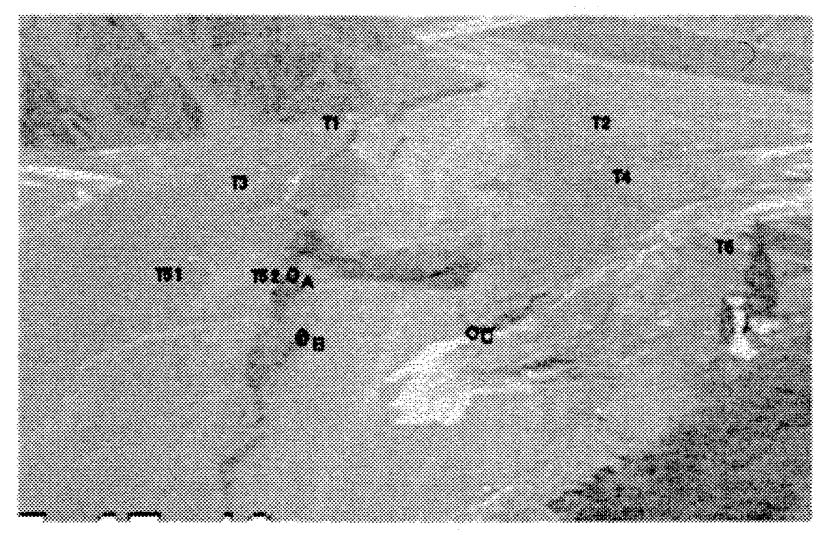

写真 -1 流下河道と基淮点の位置

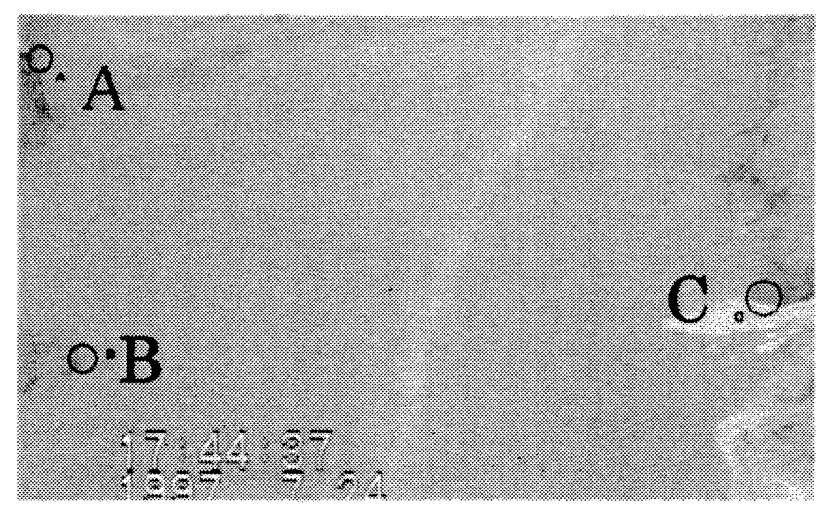

写真-2 解析画像での基準点

表一1 基淮点の座標

\begin{tabular}{|c|c|c|c|c|c|}
\hline & \multicolumn{3}{|c|}{ 実測座標 (単位 : $\mathrm{m}$ ) } & \multicolumn{2}{c|}{$\begin{array}{c}\text { 写真-1の } \\
\text { 画像座標 }\end{array}$} \\
\hline & $\mathrm{x}$ & $\mathrm{y}$ & $\mathrm{z}$ & $\mathrm{px}$ & $\mathrm{py}$ \\
\hline $\mathrm{T} 1$ & 1201.691 & 3332.975 & 1363.195 & 293 & 108 \\
\hline T2 & 1126.006 & 3304.199 & 1363.434 & 423 & 110 \\
\hline T3 & 1248.813 & 3246.858 & 1355.869 & 244 & 137 \\
\hline T4 & 1156.046 & 3221.838 & 1356.885 & 437 & 136 \\
\hline T51 & 1282.738 & 3147.398 & 1349.991 & 203 & 187 \\
\hline T52 & 1270.335 & 3143.162 & 1350.706 & 238 & 185 \\
\hline T6 & 1174.335 & 3112.100 & 1353.179 & 522 & 181 \\
\hline
\end{tabular}

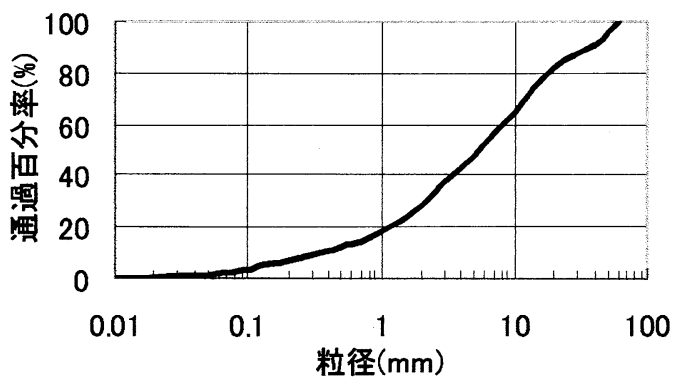

図一3 粒度曲線

ル・ビデオカメラであり, 解像度は $640 \times 480$ である. 記録した映像はインターフェイス・ボード介してコン 
ピュータに画像データとして取り込まれた．画像のサ イズを小さくするために, 幅は $640 \times 380$ としている, 解 像度の精度は損失してない（写真 2)。

ところで, 解析画像の両岸の基準点A，B，Cは光波測 距儀によって得られる画像（写真一1）加換算し, 画 像の 1 ピクセル当たりのx，y方向距離を決めている. そ れぞれの值は次のようである.

$$
\Delta \mathrm{x}=0.0593 \mathrm{~m}, \quad \Delta \mathrm{y}=0.1470 \mathrm{~m}
$$

\section{3. 解析法}

粘性土石流の表面流速の解析には相関法(PIV) を用い ている3). 相関法は, 微小時間間隔 $\Delta t$ をおいて撮られ た2枚の画像Aと Bを, 流速を求めようとする位置を中心

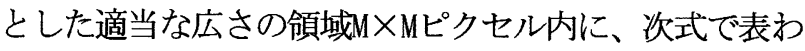
される相互相関関数を用いるものである.

$$
r_{a b}=\frac{\sum_{j} \sum_{i}\left[\frac{a_{i, j}}{\overline{a_{i, j}}}-1\right]\left[\frac{b_{i, j}}{\overline{b_{i, j}}}-1\right]}{\sqrt{\sum_{j} \sum_{i}\left[\frac{a_{i, j}}{\overline{a_{i, j}}}-1\right]^{2}} \sqrt{\sum_{j} \sum_{i}\left[\frac{b_{i, j}}{b_{i, j}}-1\right]^{2}}}
$$

ここで， $a_{i, j}$ は時刻 $\mathrm{t}$ 画像Aで, 位置 $x_{i}, y_{i}$ の位置 におけるM $\times M$ 領域内の明るさの強度であり $b_{i, j}$ は時刻 $t+\Delta t$ の画像Bで任意の $M \times M$ 領域内の明るさの強度であ る. $\overline{a_{i, j}}, \overline{b_{i, j}}$ は画像Aと $\mathrm{B}$ それぞれ明るさの強度平均 值である. ところで, 画像の明度の值はBMPファイルの RGBの平均值を用いている, 範囲は0〜255. $i, j$ は $x, y$ 方向のインデックスである. そして，画像 $\mathrm{B} て ゙$ 相関関数 が最大值 $r_{a b \text { max }}$ をもつ位置が $\Delta x_{\text {max }}, \Delta y_{\text {max }}$ であるとする と, 位置 $x_{i}, y_{i}$ での速度は $u=\Delta x_{\max } / \Delta t$, $v=\Delta y_{\max } / \Delta t$ となる

これは移動量が画像の 1 ピクセル当たりの值によっ て決められてしまうが, 相関関数の最大值の前後の值を 用いて補正することができる．ここでは放物線近似を行 い, 移動量を補正している. すなわち, 最大の相関値 $r_{2}$ の位置 $x_{2}$ とその前後の相関值 $\left(x_{1}, r_{1}\right)$ と $\left(x_{3}, r_{3}\right)$ とから，放物線近似を行うと：

$$
r=a x^{2}+b x+c
$$

から, 最大相関関数の位置xは, 次のように得られる.

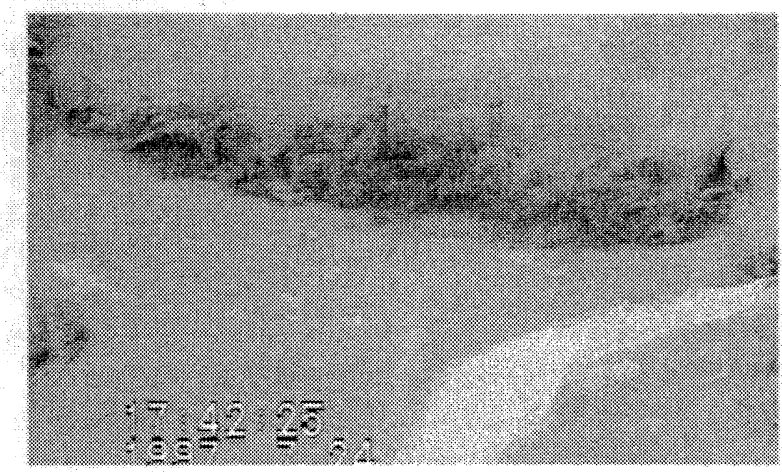

写真 -3 土石流の先端部

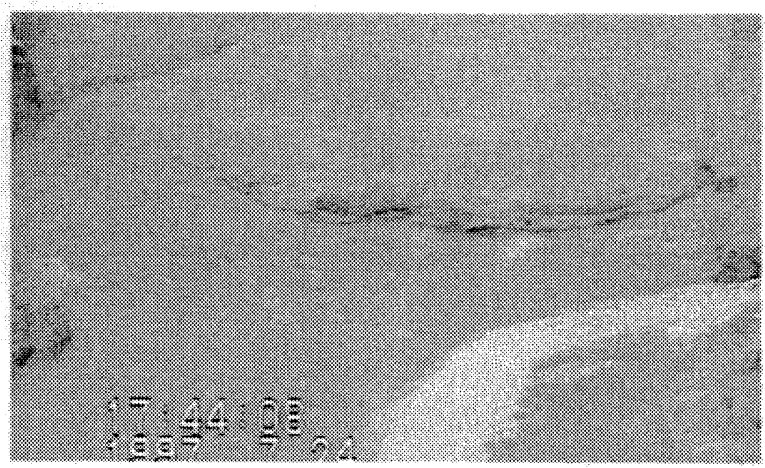

写真 -4 土石流の先端部

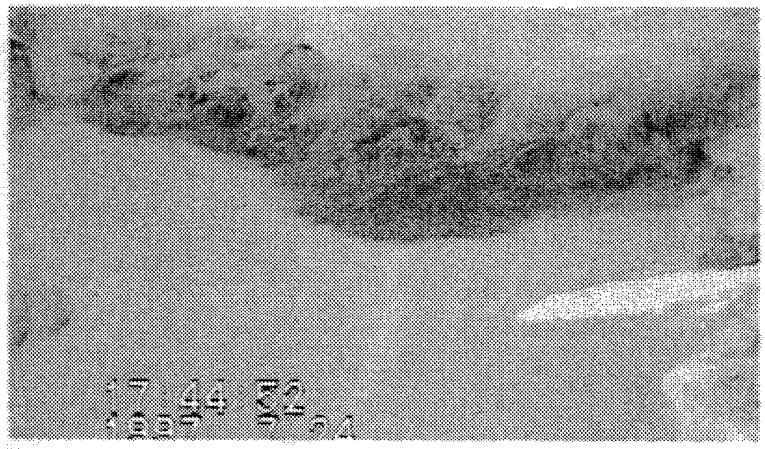

写真 -5 土石流の先端部

$x=\beta / 2 \alpha$

(3)

ここに,

$\alpha=X 1 /$ Det $\beta=X 2 /$ Det

Det $=\left[\begin{array}{lll}x_{1}{ }^{2} & x_{1} & 1 \\ x_{2}{ }^{2} & x_{2} & 1 \\ x_{3}{ }^{2} & x_{3} & 1\end{array}\right] X 1=\left[\begin{array}{lll}r_{1} & x_{1} & 1 \\ r_{2} & x_{2} & 1 \\ r_{3} & x_{3} & 1\end{array}\right] X 2=\left[\begin{array}{lll}x_{1}{ }^{2} & r_{1} & 1 \\ x_{2}{ }^{2} & r_{2} & 1 \\ x_{3}{ }^{2} & r_{3} & 1\end{array}\right]$

ここでは， $\mathrm{x}$ 方向のみ表示しているが，y方向も同様な 方法によって求めることができる. このB画面での位置 と, A画面での位置 $\left(x_{i}, y_{i}\right)$ の差が $\Delta x_{\text {max }}, \Delta y_{\text {max }}$ で ある。

また，ここでは流動面を平面として解析し，解析の テンプレートの大きさは $15 \times 15$ ピクセルを用いている. 


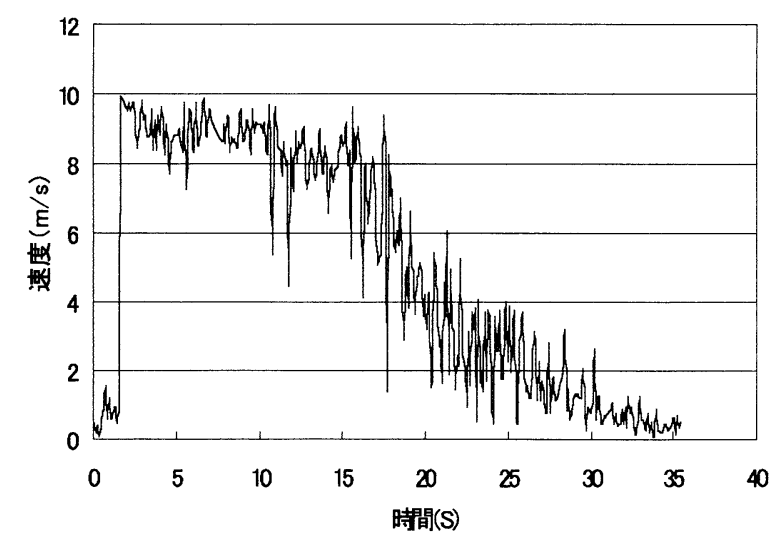

図一4 17:42:25サージの河道中央部の流速

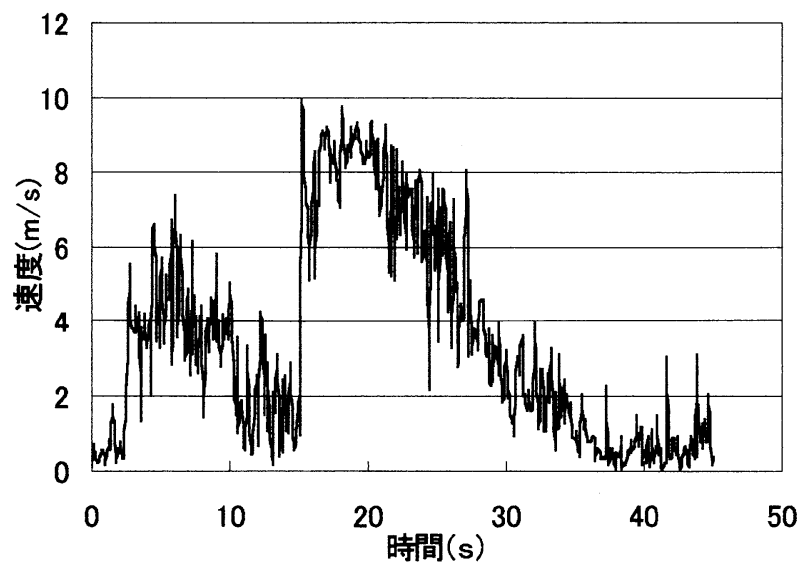

図一5 17:44:02サージの河道中央部の流速

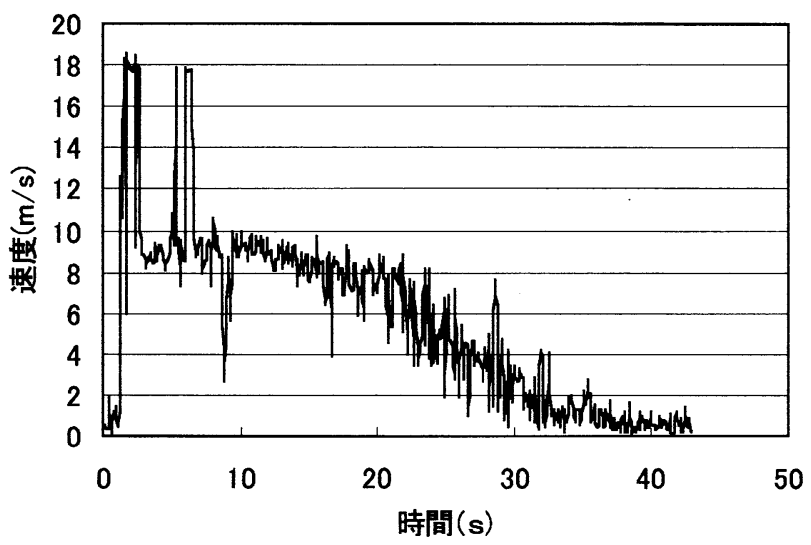

図一6 17:44:52サージの河道中央部の流速

\section{4. 解析結果及び考察}

写真-3〜写真-5 は粘性土石流の先端部分の画像例 である. 前述の相関法による解析結果は, 以下のようで ある。

a. サージの中心部の流速変化

図-4〜図一6 は流れのほぼ中央部での流速であり,

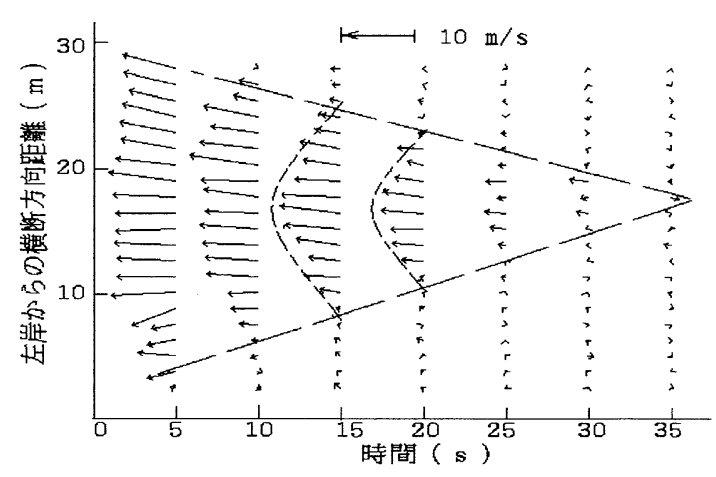

図-7 流速ベクトルの横断分布 $(17: 42: 25)$

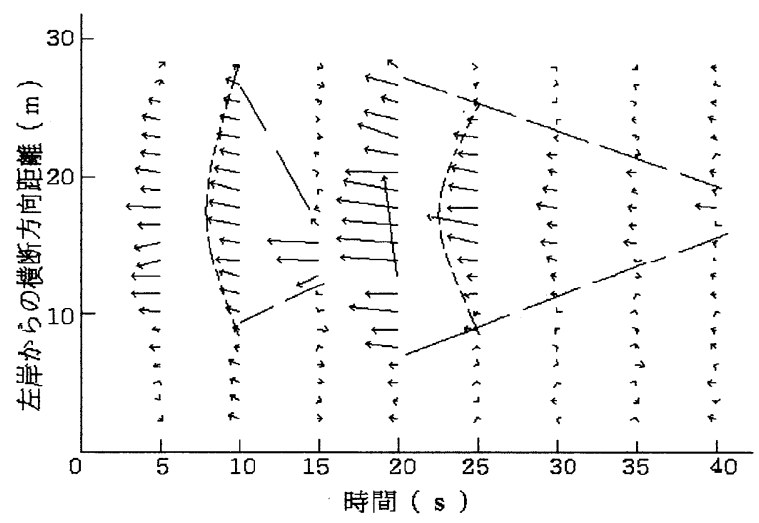

図-8 流速ベクトルの横断分布 $(17: 44: 02)$

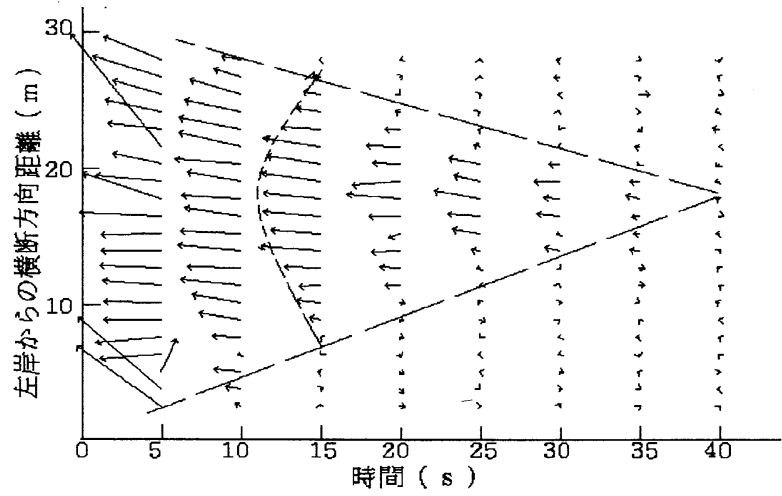

図-9 流速ベクトルの横断分布 $(17: 44: 52)$

オイラー的な表面流速の時間変化を示し，横軸に時間

(sec)，縦軸に表面流速を示している.

これらの結果によると, 一つのサージは先端部で流速 が速く，しだいに減少し，最後に停止する流れである. また, サージの先頭部や後続部に比較的流速が一定な部 分もあることがわかる

\section{b. サージの横断表面流速}

図一7〜図-9は写真-3〜 5に対応するのサージの横断 方向の流速べクトルが流下時間とともに変化する様子を 示しているものである. 横軸は時間 $(\mathrm{sec})$, 縦軸は左岸 


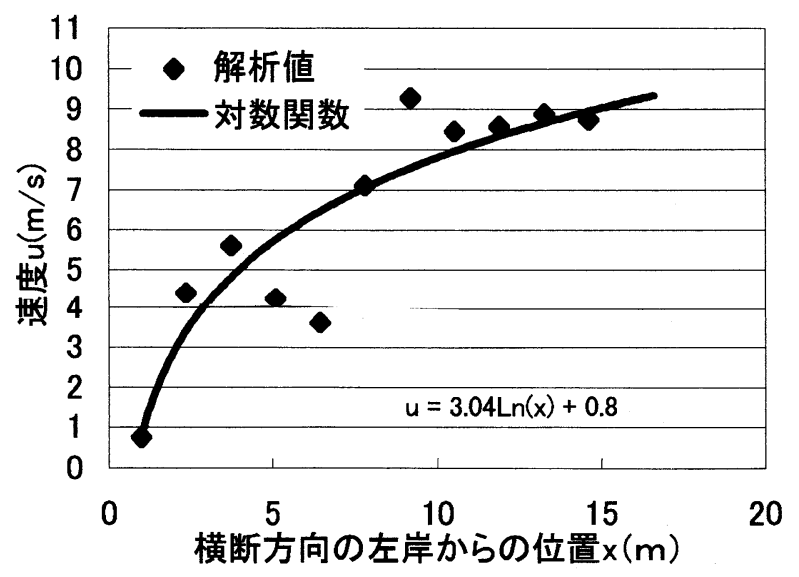

図-10 17:42:25サージの先端部の横断流速分布(左)

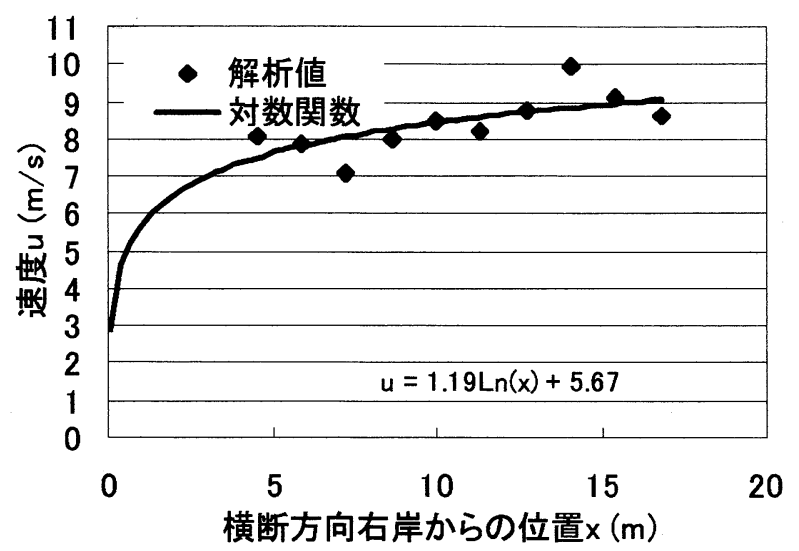

図-11 17:42:25サージの先端部の横断流速分布(右)

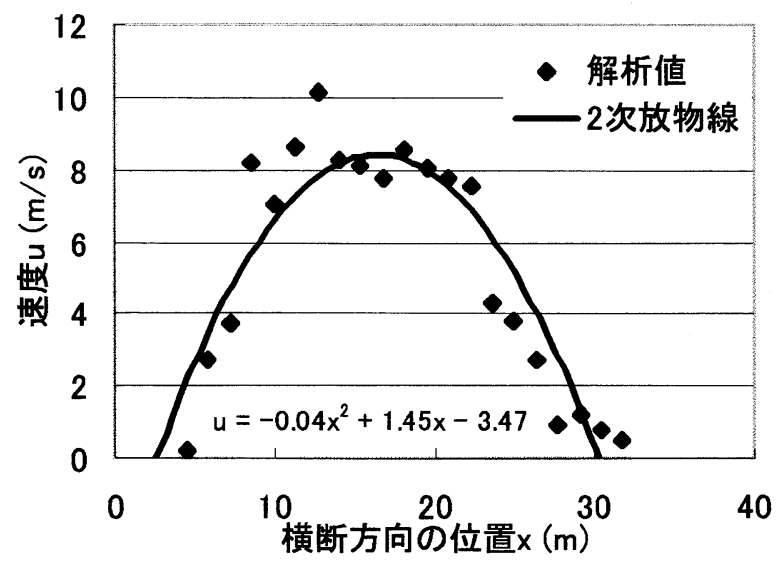

図一-12 17:42:25サージ15秒後の横断流速分布

からの距離を示している.

図中の破線は流速がほぼゼロとなっている境界をし めしている.これらによると，土石流けサージは，後続 流において流速が減少して行くとともに流下幅も減少し て行くことが示されている.また，図中の横断方向の点 線は放物線を示している.

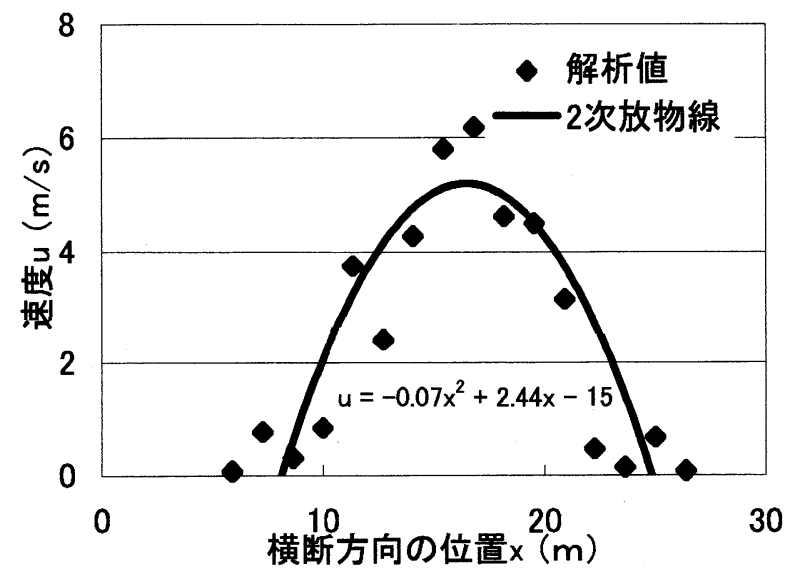

四-13 17:42:25サージ20秒後の横断流速分布

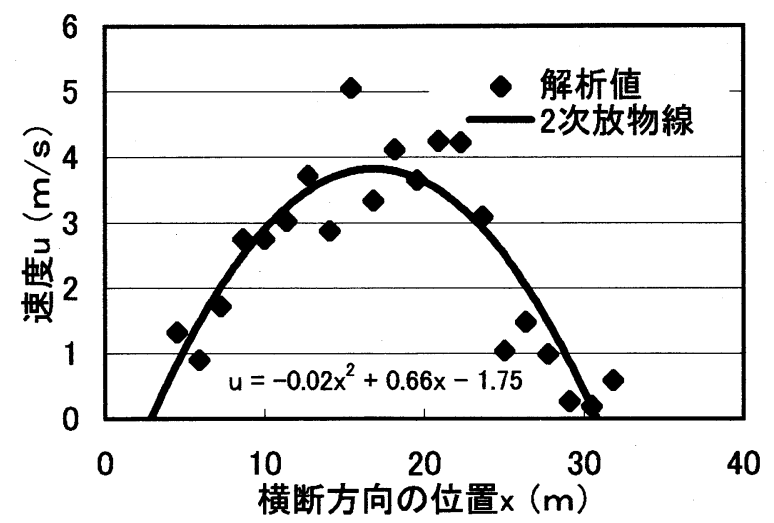

図－14 17:44:08のサージ10秒後の横断流速分布

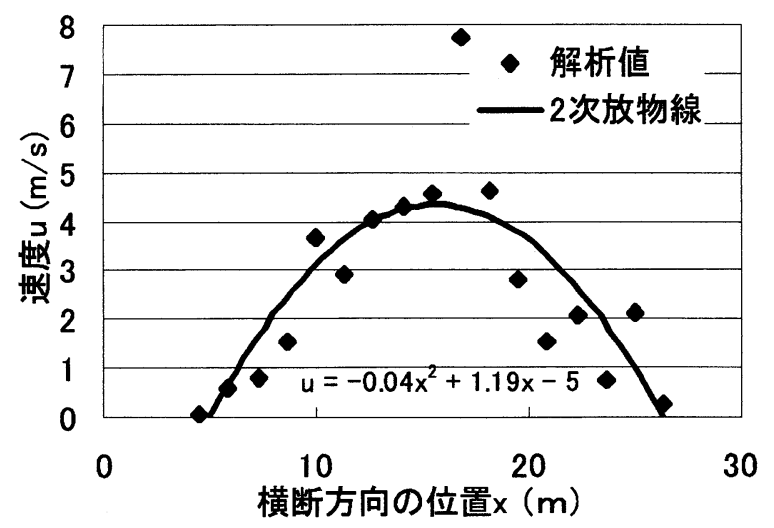

図－15 17:44:08サージ25秒後の横断流速分布

図一8, 図一9の図中に異常と思われるべクトルがある が，先の解析方法による結果をそのまま示しているもの で他の補正に行っていないためであると考えられる.

図一5, 図一8のサージでは小さなサージ0直後に，よ り大きなサージが来たことを示している.この流れの場 合，先の小さなサージは後続のサージに追いつかれ，一 
体化して流下している.

ところで，土石流サージの横断方向の流速分布形に ついて示したのが, 図ー10〜図-15である. 図一 12, 図 -13 は, 図一 4 , 図一7のサージ先端から15秒, 20秒後の 横断方向変化図である. 横軸に左岸からの距離, 点印は 流下方向の流速である. 層流とする粘性流体の場合、壁 面からの流速分布は 2 次放物線である。図中の実線は横 断流速分布に2次放物線を近似曲線として示したもので, 比較的よく対応している. これは, 粘性の効果が卓越し た流れで，一種の粘性流体であることを示している. 図 -10 , 図一11は同じ図一, 図一7に対応するもので, 先 端から5秒後の横断方向の流速分布であるが, 図一10は 流心線から左岸側の部分を示し, 図一11は流心線から右 岸側の部分を右岸からの距離で示している. 図中の実線 は対数関数を近似曲線として示したもので, 比較的良く 対応している. これは, 慣性項が卓越した流れで, 乱流 構造を有する流れであると考えられる. 図-14, 図-15 は図一5, 図一8に対応したもので, 小さなサージの先端 部，あるいは後続流の部分を示しており，それぞれ横断 方向の流速分布形は, 2次放物線の近似曲線に良く対応 している. また, いずれの場合も, サージ最末端では, 流速かゼロとなる現象となっている. 通常の流れのよう に, 指数関数的に违减する現象とは異っている.

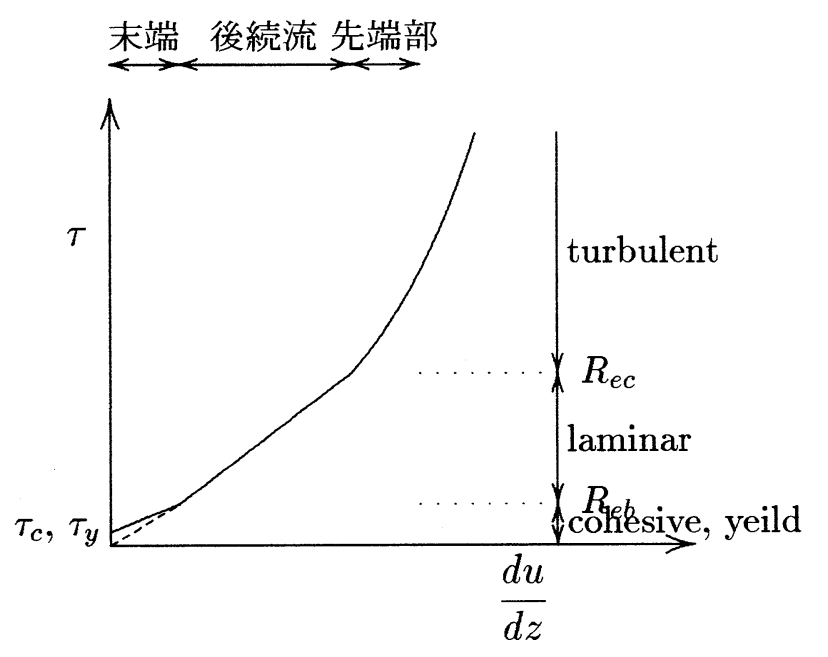

$$
\text { 図-16 } \tau-\mathrm{du} / \mathrm{dz}
$$

ところで，1995年に，この蒋家溝にそそぐ流路勾配 $13.4^{\circ}$ ，幅は約 $2 \mathrm{~m}$ ，深さ約 $0.5 \mathrm{~m}$ のガリ（gully）を用 いて実験を行なっているが 4)，5)，その結果では流れの 平均水深が $0.14 \sim 0.2 \mathrm{~m}$ で平均流速的 $0.2 \mathrm{~m} / \mathrm{s} \quad(0.085 \sim$ $0.426 \mathrm{~m} / \mathrm{s})$ というゆっくりとした流速を得ている. その
小規模な流れと実際の粘性土石流サージの先端部では慣 性項 $\left(u \frac{\partial u}{\partial x}\right)$ と粘性項 $\left(v \frac{\partial^{2} u}{\partial x^{2}}\right)$ の比であるレイルズ数 $R_{e}=U L / v$ が103程度の違いがあり, 小規模な流れで は，粘性が卓越した流れであると考えられる.

以上のことから, 図一 16 の応力 $(\tau)$ と速度勾配 $(\mathrm{du} / \mathrm{dz})$ の関係で示せば, 先端部は慣性項が卓越し, 時系 列的に微小擾乱が発達する乱流構造を有する流れであり， 後続流は粘性項が卓越した一種の層流状の粘性流体の流 れであり, 流れの最末端は, 速度勾配に依存しない粘着 力 $\left(\tau_{c}\right)$ や降伏応力 $\left(\tau_{y}\right)$ が影響する流れであると考 えられる. ただし, 流速がかなり小さな速度まで維持で きることから粘着力等の值は非常に小さいものと考えら れる.

\section{5. 結語}

以上の解析以外に 7 例の解析及び現地実験などから, 粘性土石流の流動構造は単一の構造ではなく, 先端部の 慣性項が卓越した領域では乱流構造有する流れであり， 後続流は粘性項が卓越した一種の粘性流体であり, 最末 端では粘着力や降伏応力が影響する流れであると考えら れる。

\section{参考文献}

1）中国科学院東川泥石流観測研究站, P1.

2）高橋保, 中川一, 里深好文, 緒方正隆; 粘性土石流の流動 機構に関する研究 (3), 京都大学防災研究所年報, No. 41, B-2, pp. 265-275, 1998.

3) ARAI, M. , SAWADA, T. and TAKAHASHI, T. ; An Application of Image Analysis Technique on the Velocity of Debris Flow Observation, Pro. Of $3^{\text {rd }}$ International Conference on HydroScience and Engineering, IAHR, 1998, Fie.Reserveir.188,pp1-9.

4) 諏訪浩、澤田豊明、新井宗之、高橋保、水山高久; 粘性土 石流の発生、流動、堆積のメカニズムと対策、京都大学防 災研究所年報、No. 40, IDNDR特別号、pp. 159-165, 1997。

5）新井宗之、高橋保、山谷浩司; 中国・粘性土石流の現地実 験、土木学会第52囘年次学術講演会概要集、II- 228, pp. 456-457，1997。

(1999. 9. 30受付) 